\title{
Bioactive Compounds in the Ethanol Extract of Marine Sponge Stylissa carteri Demonstrates Potential Anti-Cancer Activity in Breast Cancer Cells
}

\author{
Muhammad Hasan Bashari, ${ }^{1,2 *}$, Fathul Huda ${ }^{2,3}$, Tamia S Tartila ${ }^{4}$, Sarah Shabrina ${ }^{4}$, \\ Tenny Putri ${ }^{5}$, Nurul Qomarilla ${ }^{5}$, Harold Atmaja ${ }^{5}$, Beginer Subhan ${ }^{6}$, Ikhwan \\ Resmala Sudji ${ }^{7}$, Edy Meiyanto ${ }^{8}$
}

\begin{abstract}
Objective: Despite advanced treatment options available, drug resistance develops in breast cancer (BC) patients requiring novel effective drugs. Stylissa carteri, a marine sponge predominantly living in Indonesia territories, has not been extensively studied as anti-cancer. Therefore, this study targeted to assess the anti-tumor activity of the ethanol extract of $S$. carteri in BC cells. Methods: $S$. carteri was collected from Pramuka Island, at Kepulauan Seribu National Park, Jakarta, Indonesia and extracted using ethanol. Different BC cells including MDA MB 231, MDA MB 468, SKBR3, HCC-1954 and MCF-7 cells were treated with this extract for cytotoxic analysis using MTT assay. Spheroid growth assay and apoptosis assay were conducted in HCC-1954 cells. In addition, cell migration analysis and synergistic activity with doxorubicin or paclitaxel were conducted in MDA MB 231 cells. This extract was subjected also for GC-MS analysis. Results: The results show that ethanol extract of $S$. carteri demonstrated a cytotoxic activity in $\mathrm{BC}$ cells. The $\mathrm{IC}_{50}$ of this extract was lower $15 \mu \mathrm{g} / \mathrm{ml}$ in MDA MB 231, MDA MB 468, SKBR3, and HCC-1954 cells. Moreover, this extract inhibited spheroids growth and induced apoptosis in HCC-1954 cells. It inhibited cell migration and demonstrated a synergistic activity with doxorubicin or paclitaxel on triggering cell death in MDA MB 231 cells. Furthermore, GC-MS analysis indicated that this extract contained 1,2-Benzenediol, Dibutyl phthalate and 9,12-Octadecadienoic acid, ethyl ester. Conclusion: Our preliminary data indicate a potential anti-tumor activity of ethanol extract of $S$. carteri in breast cancer cells.
\end{abstract}

Keywords: Anti-cancer activity- breast cancer- marine sponge- Stylissa carteri

Asian Pac J Cancer Prev, 20 (4), 1199-1206

\section{Introduction}

Breast cancer $(\mathrm{BC})$ is the first most diagnosed cancer in women worldwide, and they are becoming first main cause of cancer-related deaths in women, respectively (Torre et al., 2015). The high prevalence and mortality by $\mathrm{BC}$ along with weaknesses of existing managements and prevention raise the urgency and need for discovery of novel drugs (Aungsumart et al., 2007; Torre et al., 2015).

Despite advanced BC treatment modalities are available, advanced stage of $\mathrm{BC}$ patients, develop resistant to current therapeutic options. Chemotherapy resistance leads into cancer progression and metastasis, thereby it remains as the greatest challenges in cancer management and responsible to cancer-related death (Hammond et al., 2016). Therefore, it is urgent to discover a novel drug for $\mathrm{BC}$ to overcome the resistance and provide better treatment response, which will lead in improving the survival of patients with $\mathrm{BC}$.

Marine sponges have been explored worldwide for novel anti-cancer agents. One of successfully active compound originated from marine sponge is Eribulin, which has been approved by American Food and Drug Administration (FDA) for the advanced stage of triple negative BC (Candida et al., 2012). Moreover, a novel promising compound, Leiodermatolide, was just synthesized based on an isolated compound from deep marine sponges, Leiodermatium sp. from Florida. This

${ }^{1}$ Department of Biomedical Sciences, Division of Pharmacology and Therapy, ${ }^{2}$ Oncology and Stem Cell Working Group, ${ }^{3}$ Department of Biomedical Sciences, Division of Physiology, ${ }^{4}$ Undergraduate Program, ${ }^{5}$ Laboratory of Advanced Biomedicine, Faculty of Medicine, Universitas Padjadjaran, Bandung, ${ }^{6}$ Department of Marine Science and Technology, Faculty of Fisheries and Marine Sciences, Bogor Agricultural University, Bogor, ${ }^{7}$ Laboratory of Biomedicine, Faculty of Medicine, Universitas Andalas, Padang, ${ }^{8}$ Cancer Chemoprevention Research Center, Faculty of Pharmacy, Universitas Gadjah Mada, Yogyakarta, Indonesia. *For Correspondence: bashari@unpad.ac.id 
compound demonstrates a powerful anti-tumor activity compared to paclitaxel in prostate cancer cells (Guzmán et al., 2016). Above data indicating that sponges are very potential to be studied for novel anti-cancer drug discovery.

Indonesia as an archipelago country possesses botanical biodiversity potential that incompletely developed for novel cancer treatment. Here we evaluate S. carteri for its anti-tumor activities. S. carteri are widespread in Indo-Pacific region, including the red sea, Australian sea and many Indonesian territories (Erpenbeck et al., 2017). To date studies subjected this species for its anti-tumor activities are very limited. Nevertheless, a recent study shows that an isolated compound from $S$. carteri induces cervical cancer Hela cells death (Dewi, 2017). This study wanted to identify anti-tumor activities of ethanol extract of marine sponge $S$. carteri in different $\mathrm{BC}$ cells.

\section{Materials and Methods}

\section{Chemicals and reagents}

RPMI 1640 medium (cat No. 11875093), Dulbecco's modified Eagle's medium (DMEM) (cat no 11965-092), fetal bovine serum (FBS) (cat No. 10270106), non-essential amino acid and penicillin streptomycin (cat No. 15140122) were purchased from Gibco, USA. Dimethyl sulfoxide (DMSO) (cat No. D8418), and 3-[4,5-dimethylthiazol-2-yl]-2,5 diphenyl tetrazolium bromide (MTT) (cat No. M2128), were purchased from Sigma-Aldrich, USA. Doxorubicin and Paclitaxel were provided by Pharmacy of Hasan Sadikin Hospital, Bandung, Indonesia. All the other chemicals were of analytical grade purchased from Merck, USA.

\section{Extraction of Stylissa carteri}

Marine sponge $S$. carteri was taken by SCUBA diving from different sites at 10 meters depth in Pramuka Island, which constitutes the Kepulauan Seribu Marine National Park located in the north of Jakarta, Indonesia (Figure 1). Species were visually identified in the field, and confirmed at Department of Marine Science and Technology, Faculty of Fisheries and Marine Sciences, Bogor Agricultural University. Samples were cut into small size and then extracted using maceration technic in ethanol according to previous study (Hardani et al., 2018).

\section{Cell culture and conditions}

The triple negative (TN) BC cells (MDA MB 231, MDA MB 468), HER2+ BC cells (SKBR3, HCC-1954) and luminal A BC cells (MCF-7) were used to evaluate the anti-tumor activity of $\mathrm{Et}(\mathrm{OH})$ extract of $S$. carteri. The MDA MB 231 and MDA MB 468 cells were from Dr. Thordur Oskarsson (DKFZ, Germany), SKBR3 cells were from Prof. Andreas Trumpp (DKFZ, Germany), HCC-1954 cells were from Prof. Stefan Wiemann (DKFZ, Germany), MCF-7 cells were from Dr. Ahmad Faried and Prof. Hiroyuki Kuwano.

SKBR3 cells were cultured using DMEM supplemented with non-essential amino acid, 10\% heat-inactivated FBS, $1 \%$ penicillin/streptomycin and $2 \mathrm{mM}$ L-glutamine in a regular cell culture incubator that contained $21 \% \mathrm{O}_{2}$, $5 \% \mathrm{CO}_{2}, 37^{\circ} \mathrm{C}$. All the other cell lines were cultured using RPMI 1640 medium supplemented with 10\% heat-inactivated FBS, 1\%. All experiments were conducted triplicate and from 3 different experiments at Laboratory of cell culture and cytogenetic, Faculty of Medicine, Universitas Padjadjaran, Indonesia.

\section{Cytotoxicity assay}

To evaluate cytotoxic activity of the $\mathrm{Et}(\mathrm{OH})$ extract of $S$. carteri in BC cells, we used MTT assay, as previously described (Vallet et al., 2016). Cell lines were seeded on 98-well plate a day before untreated or treated with the $\mathrm{Et}(\mathrm{OH})$ extract as indicated concentrations then incubated for 72 hours. At the last day, MTT solution was added 4 hours before stopped by DMSO. Samples were read at $550 \mathrm{~nm}$ with a plate reader (Thermo Scientific ${ }^{\circledR}$ Multiscan EX, Singapore).

\section{Spheroid formation assay}

Single multicellular BC spheroids were generated according previous study (Bashari et al., 2016). Briefly, a number of 9,000 HCC-1954 cells were seeded on agarose-coated (Sigma Aldrich, Steinheim, Germany) 96-well plates followed by 4 days incubation for initiation of spheroid formation. Spheroids were then treated or untreated with $\mathrm{Et}(\mathrm{OH})$ extract of Stylissa carteri. Spheroids were captured with the microscope using the camera connected with a computer and Toupview Software (version x64, 3.7.7892) using 40x magnifications. Images were analyzed using ImageJ software to have spheroid radius. Volumes of the spheroids were calculated $(V=4 / 3$ $\left.\pi r^{3}\right)$.

\section{Apoptosis assay}

In order to identify apoptosis induced cell death triggered by the $\operatorname{Et}(\mathrm{OH})$ extract of $S$. carteri, we used Dead Cell Apoptosis Kit with Annexin V FITC and PI (Invitrogen, cat.no. V13242). After HCC-1954 cells were growth on 6-well plate, cells were treated and un-treated with the $\mathrm{Et}(\mathrm{OH})$ extract of $S$. carteri for 48 hours. Cells were harvested followed by stained with Annexin V/PI according to manufacture protocol. Cell suspension were then placed on an object glass followed by captured using Olympus fluorescence microscope BX51 using the camera connected with a computer and Toupview Software (version x64, 3.7.7892) using 100x magnifications. Images were stacked using ImageJ software.

\section{Combination index}

Cells were treated with different concentration of $\mathrm{Et}(\mathrm{OH})$ extract of $S$. carteri alone or in combination with doxorubicin, or paclitaxel followed by the cytotoxic assay. Combination index was analyzed with Compusyn software based on Chou Talalay method (Chou, 2010).

\section{Migration Assay}

To assess the anti-cell migration of $\mathrm{Et}(\mathrm{OH})$ extract of Stylissa carteri, we were conducted scratch/wound healing assay in MDA MB 231 cells according to previous study (Vallet et al., 2016). After gaps were created, cells were 
treated or untreated with $\mathrm{Et}(\mathrm{OH})$ extract of $S$. carteri in complete medium then placed in incubator. The 0 th and 24th hour of treatment were captured under the microscope which connected with a computer and Toupview Software (version x64, 3.7.7892) and saved as TIFF. The gap area was measured using MRI Wound Healing Tool macro for ImageJ software (NIH) (http://dev.mri.cnrs.fr/projects/ imagejmacros/wiki/Wound_Healing_Tool).

\section{GC/MS analysis}

The GC/MS analyses were carried out on Shimadzu single quadrupole GCMS-QP2010 Ultra gas chromatograph-mass spectrometer according to previous study (Vetvicka and Vetvickova, 2016). Briefly, the GC was equipped with a $30 \mathrm{~m}$ x $0.25 \mathrm{~mm}$ RP-5 non-polar column (Shimadzu) with $0.251 \mathrm{~m}$ film thicknesses. The MS was run in the electron impact ionization mode with an ionizing energy of $70 \mathrm{eV}$, scanning from $\mathrm{m} / \mathrm{z}$ 1 to 2,000 at $0.3 \mathrm{scan} / \mathrm{sec}$. The ion source temperature was $300^{\circ} \mathrm{C}$, and the quadrupole temperature was $280^{\circ} \mathrm{C}$ while the electron multiplier voltage was maintained at $0.8 \mathrm{kV}$. The chromatographic conditions were identical to those used for gas chromatography analysis. Helium was used as carrier gas, the flow through the column was $1 \mathrm{~mL} / \mathrm{min}$, and the split ratio was set to 400:1. The column was maintained at $40^{\circ} \mathrm{C}$ for $10 \mathrm{~min}$, increased to $180^{\circ} \mathrm{C}$ at a rate of $2.5^{\circ} \mathrm{C} / \mathrm{min}$, and finally maintained at a rate of $20 \mathrm{~min}$. Injection volume of the sample was $0.2 \mu \mathrm{L}$. For the identification of the compounds, retention times and retention index were confirmed with database from software NIST11 Mass Spectral Library.

\section{Statistical analysis}

Four-parametric-logistic model by Sigmaplot for windows ver. 12 software (Systat Software Inc) was used to generate drug curves and to analyze $\mathrm{IC}_{50}$. Anova test and posthoc Holm-Sidak method were used to determine the statistical significance of differences observed in treated versus control cultures. Data was significantly different if $\mathrm{p}<0.05$.

\section{Results}

The Et $(\mathrm{OH})$ extract of $S$. carteri has cytotoxic activity in $B C$ cell lines

Cytotoxic effects of the $\operatorname{Et}(\mathrm{OH})$ extract of $S$. carteri were evaluated using MTT assay in different BC cell lines including the TNBC cells, MDA MD 231 and MDA MB 468; HER2+ cells, SKBR3, and HCC-1954 as well as $\mathrm{ER}+\mathrm{BC}$ cells, MCF-7. Our data revealed that the $\mathrm{Et}(\mathrm{OH})$ extract of $S$. carteri induced cell death in all BC cells lines in dose dependent manner (Figure 2A-E). The $\mathrm{IC}_{50}$ of the $\mathrm{Et}(\mathrm{OH})$ extract of $S$. carteri were less than $90 \mu \mathrm{g} / \mathrm{ml}$ in all tasted $\mathrm{BC}$ cell lines (Figure 2F). Interestingly, the $\mathrm{IC}_{50}$ of the $\mathrm{Et}(\mathrm{OH})$ extract of $S$. carteri were lower in the aggressive BC subtype cells, TNBC and HER2+ than in $\mathrm{ER}+\mathrm{BC}$ cells (Figure 2F).

The Et(OH) extract of S. carteri inhibits spheroid growth and induces apoptosis in HCC-1954 cells

Next, we evaluate effects of the $\operatorname{Et}(\mathrm{OH})$ extract of $S$. carteri in BC cells using 3-dimentional culture system. Spheroids of HCC-1954 were treated or untreated with the $\mathrm{Et}(\mathrm{OH})$ extract of $S$. carteri. Data showed that the $\mathrm{Et}(\mathrm{OH})$ extract of $S$. carteri induced declining of $\mathrm{BC}$ spheroids volumes along with incubation periods (Figure 3A-C). Importantly, the $\operatorname{Et}(\mathrm{OH})$ extract of $S$. carteri induced apoptosis in HCC-1954 cells (Figure 3D-G).

\section{The Et $(\mathrm{OH})$ extract of $S$. carteri inhibits TNBC cell} migration in dose dependent manner

Migration of cancer cells is one of the key aspects of cancer metastasis. Therefore, we then wonder whether the $\operatorname{Et}(\mathrm{OH})$ extract of $S$. carteri able to inhibit BC cell migration. Utilizing a basic cell migration assay, wound healing assay, the aggressive TNBC cells, MDA MB 231 cells were treated with low concentration of $\mathrm{Et}(\mathrm{OH})$ extract of $S$. carteri. In control group, the gap in MDA MB 231 cells was closed while in the treated groups, the gaps were still opened. Both concentrations of $\mathrm{Et}(\mathrm{OH})$ extract of $S$. carteri significantly inhibited MDA MB 231 cells migration $(\mathrm{p}<0.05)$ (Figure 4).

The Et $(\mathrm{OH})$ extract of $S$. carteri induces synergistic cell death with conventional chemotherapy agents in TNBC cells

Heretofore our data showed a promising anti-tumor activity of the $\operatorname{Et}(\mathrm{OH})$ extract of $S$. carteri by inducing cell death and inhibiting cell migration. Considering that cancer cells were activating multiple pathways for resisting from cell death, it is important to target cancer cell with multiple agents. Here we evaluated the combination effect of $\operatorname{Et}(\mathrm{OH})$ extract of $S$. carteri with paclitaxel or with doxorubicin as two of main $\mathrm{BC}$ chemotherapy regiment.
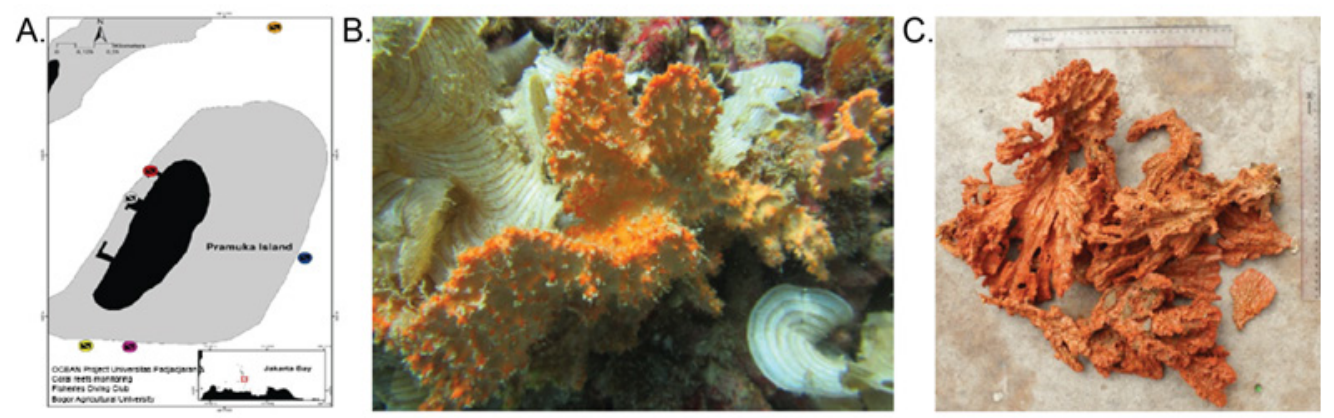

Figure 1. Stylissa Carteri was Taken from Different Sites in Pramuka Island. (A) Collected sites of Stylissa carteri. Stylissa carteri was on coral (B) and after was taken (C). 

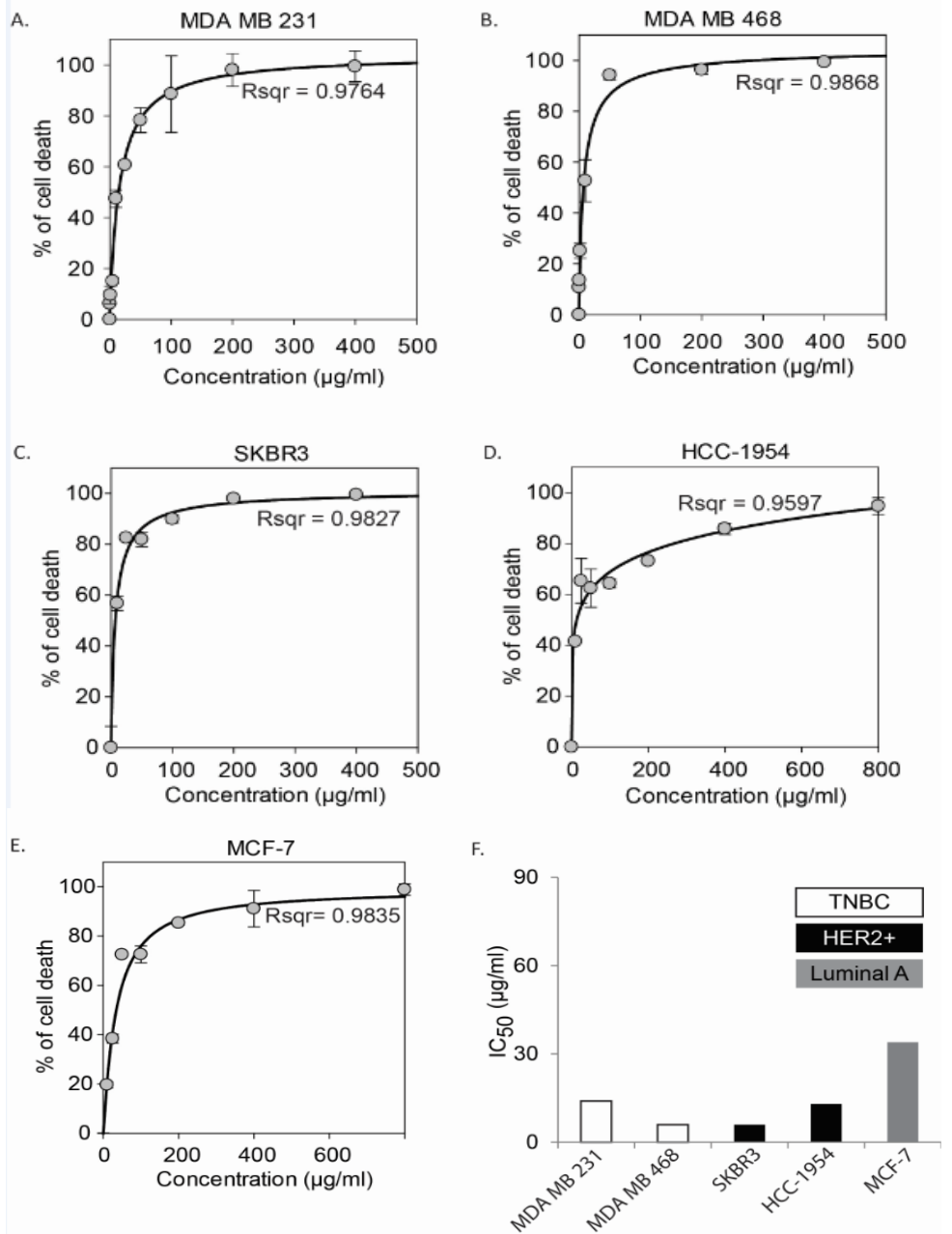

Figure 2. The Et (OH) Extract of $S$. Carteri Triggers Cell Death in BC Cell Lines in Dose Dependent Manner. BC cell lines were treated with $\mathrm{Et}(\mathrm{OH})$ extract for 72 hours followed by cytotoxic analysis using MTT assay. Medium with $1 \%$ DMSO was used as control. Data were presented as mean and SD from triplicate data. Drug curves (A-E) were created and $\mathrm{IC}_{50}$ of each cell lines $(\mathrm{F})$ were analyzed using four parametric logistic model by Sigmaplot ver. 12.
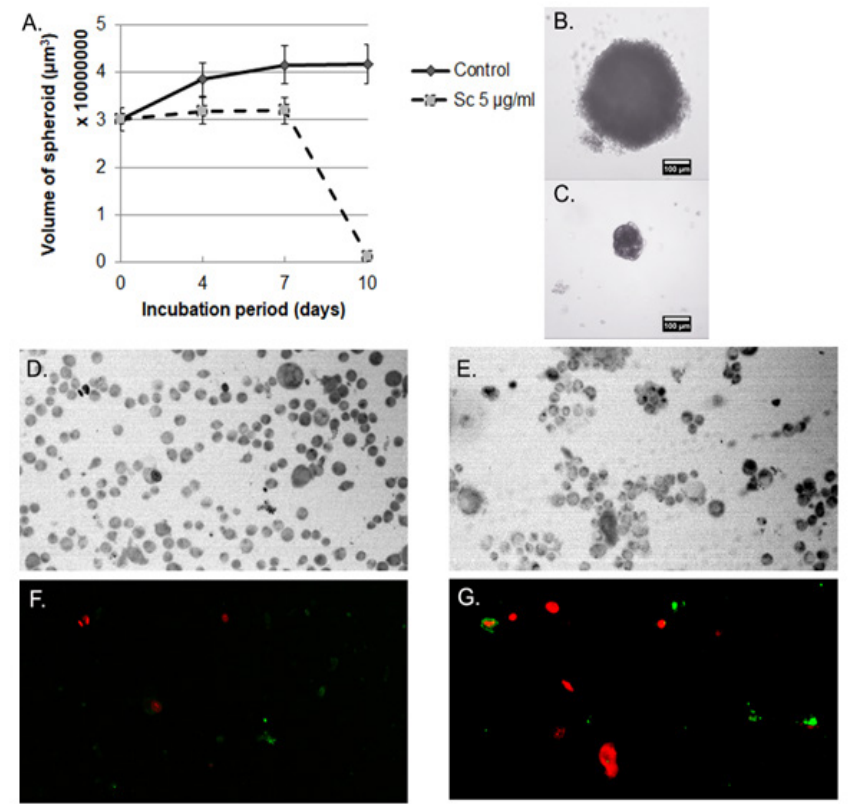

Figure 3. The Et $(\mathrm{OH})$ extract of $S$. carteri Inhibits Spheroid Growth and Induces Apoptosis of HCC-1954 Cells. After spheroids of HCC-1954 were generated, they were treated and untreated with $5 \mu \mathrm{g} / \mathrm{ml}$ of the $\operatorname{Et}(\mathrm{OH})$ extract of S. carteri. (A) Spheroid volumes were declined upon treatment. Spheroid mass on day 10th represented of control (B) and treated group (C). Data was presented as mean and SD of 7 replicates each group. HCC-1954 cells were un-treated $(\mathrm{D}, \mathrm{F})$ and treated $(\mathrm{E}, \mathrm{G})$ with $5 \mu \mathrm{g} / \mathrm{ml}$ of the $\mathrm{Et}(\mathrm{OH})$ extract of $S$. carteri for 48 hours followed by Annexin V (green)/ PI (red) staining and captured under Olympus Fluorescence microscope with 100x magnification. D, E=bright field; $\mathrm{F}, \mathrm{G}=$ Fluorescence. 


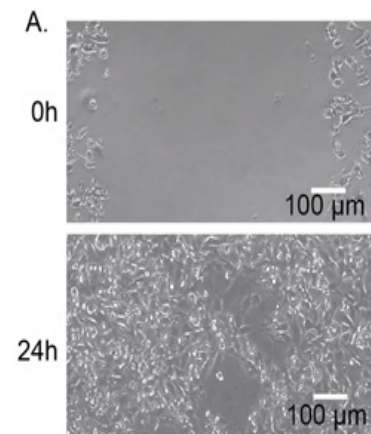

Control
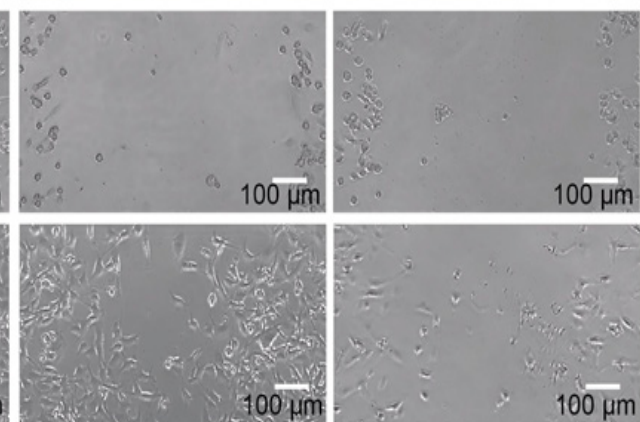

$0.5 \mu \mathrm{g} / \mathrm{ml}$

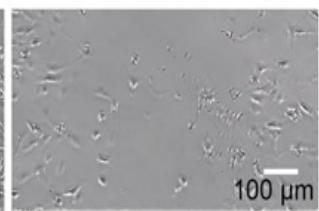

$1 \mu \mathrm{g} / \mathrm{ml}$

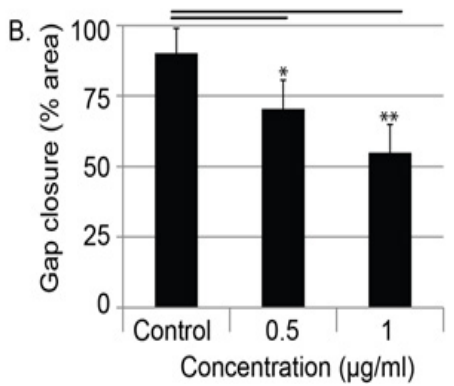

Figure 4. The Et $(\mathrm{OH})$ Extract of $S$. carteri Inhibits Cell Migration of MDA MB 231 in Dose Dependent Manner. MDA MB 231 cells were scratched prior treated with indicated concentration of the $\operatorname{Et}(\mathrm{OH})$ extract for 24 hours. Cell gaps were capture. Medium with 1\% DMSO was used as control. Data were presented as mean and SD from triplicate data. $* \mathrm{p}<0.05 ; * * \mathrm{p}<0.01$ to control.

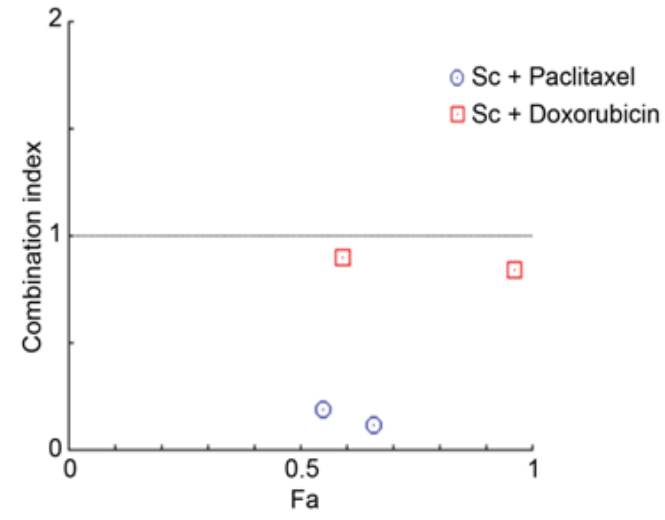

Figure 5. Combination of the Et $(\mathrm{OH})$ Extract of $S$. carteri with Conventional BC Chemotherapy Agents Induces Synergism in TNBC Cells. MDA MB 231 cells were treated $\mathrm{Et}(\mathrm{OH})$ extract of $S$. carteri $(\mathrm{Sc}) 2 \mu \mathrm{g} / \mathrm{ml}$ or $10 \mu \mathrm{g} / \mathrm{ml}$ in combination with paclitaxel 1 or $4 \mathrm{nM}$ and doxorubicin 1 or $4 \mathrm{nM}$ for 72 hours prior cytotoxic assay using MTT assay. Combination index was analyzed using Compusyn Software.
Importantly, these combinations trigger synergistic effect on cell death of TNBC cells (Figure 5).

\section{GC-MS data of the Et $(\mathrm{OH})$ extract of $S$. carteri}

The compounds detected in the $\operatorname{Et}(\mathrm{OH})$ extract of $S$. carteri were identified by GC-MS analysis (Figure $6)$. Based on chromatogram, it was indicated that the prominent compounds in the $\operatorname{Et}(\mathrm{OH})$ extract of $S$. carteri were 1,2-Benzenediol, Dibutyl phthalate and 9,12-Octadecadienoic acid, ethyl ester (Table 1).

\section{Discussion}

Marine sponges have been studied worldwide for its anti-tumor activities. However, there are very limited studies on $S$. carteri for its anti-cancer activities. Alkaloid compounds, (Z)-debromohymenialdisine dan (Z)-hymenialdisine from methanol extract of $S$. carteri reveals a cytotoxic effects in MONO-MAC-6 leukemic cells (Eder et al., 1999). Similarly, an alkaloid compounds

TIC

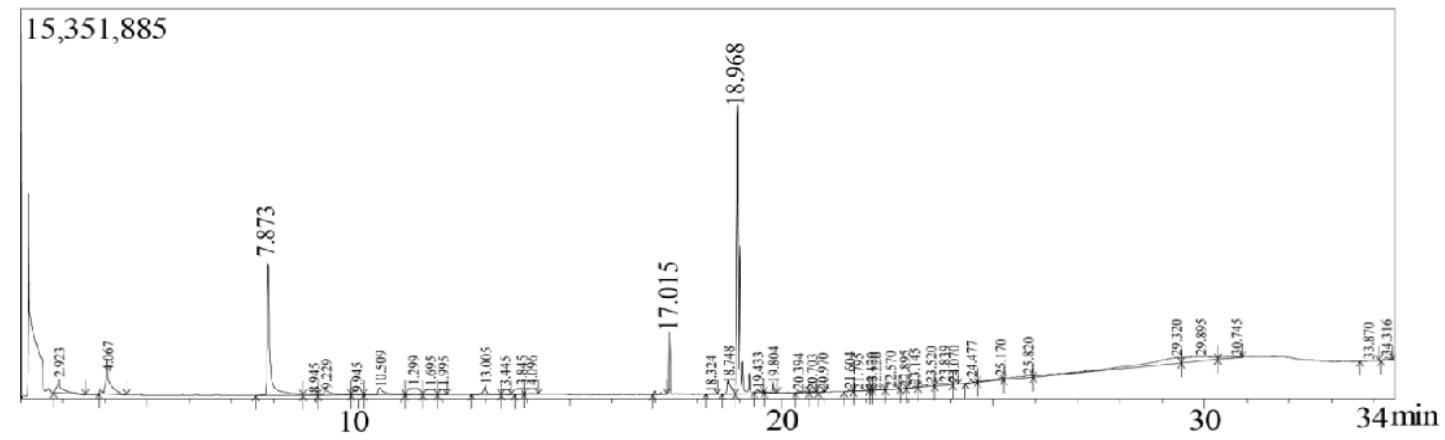

Figure 6. GC-MS Chromatogram of the Ethanol Extract of $S$. carteri 
Table 1. Compounds Detected in the Ethanol Extract of Stylissa carteri

\begin{tabular}{|c|c|c|c|c|}
\hline S.No & RT & Peak \% & Name & Molecular formula \\
\hline 1 & 2.923 & 2.34 & Propane, 1,1-diethoxy-2-methyl & $\mathrm{C}_{8} \mathrm{H}_{18} \mathrm{O}_{2}$ \\
\hline 2 & 4.067 & 6.05 & Butane, 1,1-diethoxy-3-methyl & $\mathrm{C}_{9} \mathrm{H}_{20} \mathrm{O}_{2}$ \\
\hline 3 & 7.873 & 23.9 & 1,2-Benzenediol & $\mathrm{C}_{6} \mathrm{H}_{6} \mathrm{O}_{2}$ \\
\hline 4 & 8.945 & 0.22 & Phenol, 4-ethyl-2-methoxy & $\mathrm{C}_{9} \mathrm{H}_{12} \mathrm{O}_{2}$ \\
\hline 5 & 9.229 & 1.06 & 1,2-Benzenediol, 4-methyl & $\mathrm{C}_{7} \mathrm{H}_{8} \mathrm{O}_{2}$ \\
\hline 6 & 9.945 & 0.21 & Phenol, 2,6-dimethoxy & $\mathrm{C}_{8} \mathrm{H}_{10} \mathrm{O}_{3}$ \\
\hline 7 & 10.509 & 1.31 & 1,3-Benzenediol, 4-ethyl & $\mathrm{C}_{8} \mathrm{H}_{10} \mathrm{O}_{2}$ \\
\hline 8 & 11.299 & 0.24 & Phenol, 4-ethyl-2-methoxy & $\mathrm{C}_{9} \mathrm{H}_{12} \mathrm{O}_{2}$ \\
\hline 9 & 11.695 & 0.13 & Cyclooctene, 3-methyl & $\mathrm{C}_{9} \mathrm{H}_{16}$ \\
\hline 10 & 11.995 & 0.15 & Naphthalene, 1,2,3,4,4a,5,6,8a-octahydro-4a,8 & $\mathrm{C}_{15} \mathrm{H}_{24}$ \\
\hline 11 & 13.005 & 1.62 & Diethyl Phthalate & $\mathrm{C}_{12} \mathrm{H}_{14} \mathrm{O}_{4}$ \\
\hline 12 & 13.445 & 0.11 & 7-Benzofuranol, 2,3-dihydro-2,2-dimethyl & $\mathrm{C}_{10} \mathrm{H}_{12} \mathrm{O}_{2}$ \\
\hline 13 & 13.845 & 0.12 & Esculetin & $\mathrm{C}_{9} \mathrm{H}_{6} \mathrm{O}_{4}$ \\
\hline 14 & 14.096 & 0.16 & 3,6-Dioxaoctanedioic acid & $\mathrm{C} 12 \mathrm{H} 22 \mathrm{O} 2$ \\
\hline 15 & 17.015 & 0.54 & Dibutyl phthalate & $\mathrm{C}_{16} \mathrm{H}_{22} \mathrm{O}_{4}$ \\
\hline 16 & 18.324 & 0.16 & Linoleic acid ethyl ester & $\mathrm{C}_{20} \mathrm{H}_{36} \mathrm{O}_{2}$ \\
\hline 17 & 18.748 & 2.61 & cis-9,cis-12-Octadecadienoic acid & $\mathrm{C}_{18} \mathrm{H}_{32} \mathrm{O}_{2}$ \\
\hline 18 & 18.968 & 49.26 & 9,12-Octadecadienoic acid, ethyl ester & $\mathrm{C}_{20} \mathrm{H}_{36} \mathrm{O}_{2}$ \\
\hline 19 & 19.433 & 0.51 & Linoleic acid ethyl ester & $\mathrm{C}_{20} \mathrm{H}_{36} \mathrm{O}_{2}$ \\
\hline 20 & 19.804 & 1.47 & Linoleic acid ethyl ester & $\mathrm{C}_{20} \mathrm{H}_{36} \mathrm{O}_{2}$ \\
\hline 21 & 20.394 & 0.57 & 8,10-Hexadecadien-1-ol & $\mathrm{C}_{16} \mathrm{H}_{30} \mathrm{O}$ \\
\hline 22 & 20.703 & 0.14 & Ethyl 9-hexadecenoate & $\mathrm{C}_{18} \mathrm{H}_{34} \mathrm{O}_{2}$ \\
\hline 23 & 20.97 & 0.18 & Pentadecanoic acid & $\mathrm{C}_{19} \mathrm{H}_{38} \mathrm{O}_{2}$ \\
\hline 24 & 21.604 & 0.27 & 6,9-Pentadecadien-1-ol & $\mathrm{C}_{15} \mathrm{H}_{28} \mathrm{O}$ \\
\hline 25 & 21.795 & 0.06 & Fatty Acid & $\mathrm{C}_{24} \mathrm{H}_{44} \mathrm{O}_{4}$ \\
\hline 26 & 22.12 & 0.2 & Hexadecanal & $\mathrm{C}_{16} \mathrm{H}_{32} \mathrm{O}$ \\
\hline 27 & 22.22 & 0.07 & Linoleic acid ethyl ester & $\mathrm{C}_{20} \mathrm{H}_{36} \mathrm{O}_{2}$ \\
\hline 28 & 22.57 & 0.12 & Heptadecanoic acid & $\mathrm{C}_{19} \mathrm{H}_{38} \mathrm{O}_{2}$ \\
\hline 29 & 22.895 & 0.11 & Pentadecanal & $\mathrm{C}_{15} \mathrm{H}_{30} \mathrm{O}$ \\
\hline 30 & 23.145 & 0.28 & Palmitic acid vinyl ester & $\mathrm{C}_{18} \mathrm{H}_{34} \mathrm{O}_{2}$ \\
\hline 31 & 23.52 & 0.47 & Hydroxy (palmitoyloxy)propyl-octadecenoate & $\mathrm{C}_{37} \mathrm{H}_{70} \mathrm{O}_{5}$ \\
\hline 32 & 23.839 & 0.4 & Hydroxy (palmitoyloxy)propyl-octadecenoate & $\mathrm{C}_{37} \mathrm{H}_{70} \mathrm{O}_{5}$ \\
\hline 33 & 24.07 & 0.19 & Docosanoic acid & $\mathrm{C}_{24} \mathrm{H}_{48} \mathrm{O}_{2}$ \\
\hline 34 & 24.477 & 0.86 & Tricyclo[20.8.0.0(7,16)]triacontane & $\mathrm{C}_{30} \mathrm{H}_{52} \mathrm{O}_{2}$ \\
\hline 35 & 25.17 & 0.58 & Cyclohexane,1,1-(oxydi-1-ethanediyl)bis methyl & $\mathrm{C}_{18} \mathrm{H}_{34} \mathrm{O}$ \\
\hline 36 & 25.82 & 0.41 & 9-Borabicyclo[3.3.1]nonane, 9-(3-pentyloxy) & $\mathrm{C}_{13} \mathrm{H}_{25} \mathrm{BO}$ \\
\hline 37 & 29.32 & 1.17 & Trilinolein & $\mathrm{C}_{57} \mathrm{H}_{98} \mathrm{O}_{6}$ \\
\hline 38 & 29.895 & 0.92 & 2-Hydroxy-3(palmitoyloxy)propyl (9)-9 octadecenoate & $\mathrm{C}_{37} \mathrm{H}_{70} \mathrm{O}_{5}$ \\
\hline 39 & 30.745 & 0.25 & 3,7,11,15-Tetramethyl-2-hexadecen-1-ol & $\mathrm{C}_{20} \mathrm{H}_{40} \mathrm{O}$ \\
\hline 40 & 33.87 & 0.07 & no hit compound & \\
\hline 41 & 34.316 & 0.5 & E,E,Z-1,3,12-Nonadecatriene-5,14-diol & $\mathrm{C}_{19} \mathrm{H}_{34} \mathrm{O}_{2}$ \\
\hline
\end{tabular}

of $S$. carteri which isolated from red sea, demonstrates cytotoxic effects in HCT-116 cells (Hamed et al., 2018). In addition, a recent study shows that the methanol crude extract of $S$. carteri has cytotoxic effects in cervical cancer HeLa cells (Dewi, 2017). Our previous data demonstrates that the $\operatorname{Et}(\mathrm{OH})$ extract of $S$. carteri triggers cell death in both parental HeLa cells and paclitaxel resistance HeLa cells (Hardani et al., 2018).
Here our data shows a promising anti-tumor activity of the $\operatorname{Et}(\mathrm{OH})$ extract of $S$. carteri in $\mathrm{BC}$ cells. The $\mathrm{Et}(\mathrm{OH})$ extract of $S$. carteri prompts BC cell death in dose dependent manner (Figure 2). Importantly, the aggressive $\mathrm{BC}$ cell types are more sensitive to this extract (Figure 2 F). Along with this finding, the $\operatorname{Et}(\mathrm{OH})$ extract of $S$. carteri degenerates spheroids and induces apoptosis in an aggressive BC cell line, HCC-1954 cells (Figure 3). 
Moreover, the $\mathrm{Et}(\mathrm{OH})$ extract of $S$. carteri not only inhibits the TNBC cell migration (Figure 4) but it also produces synergistic antitumor activity with the conventional anti-BC agents, doxorubicin and paclitaxel (Figure 5).

Sponges contain different secondary metabolites that are proposed to have anti-tumor effects. Stylisin has been isolated from genus Stylissa and demonstrated antioxidant properties as well as cytotoxic effects to cancer cells (Sima and Vetvicka, 2011). In addition, previous study shows that debromohymenialdisine (DBH), hymenialdisine (HD), and oroidin, which isolated from $S$. carteri inhibits Human Immunodeficiency Virus 1 (HIV-1) (O'Rourke et al., 2016). Based on photochemistry analysis which was conducted by Central Lab Universitas Padjadjaran with register no. S-420/LS-AK.143/2017, our Et(OH) extract of $S$. carteri contains flavonoid, triterpenoid and steroid. Moreover, using GC-MS analysis our extract showed some bioactive compounds. According to its chromatogram, this extract contained 1,2-Benzenediol, Dibutyl phthalate, 9,12-Octadecadienoic acid, ethyl ester and many other compounds (Table 1). Previous studies have been shown their effects on cancer cells. Dibutyl phthalate is considered as carcinogenic agent. This compound induced cell proliferation and invasiveness in breast cancer cells (Hsieh et al., 2012). This compound also induces apoptosis in neural cells (Wójtowicz et al., 2017). Moreover, 9,12-Octadecadienoic acid, fatty acid, was also identified from other marine sponge, Scopalina ruetzleri, which collected from South Brazilian coastline. Ethyl acetate fraction of $S$. ruetzleri induces cell death of human glioma cells and neuroblastoma cells (Biegelmeyer et al., 2015).

Having a promising data of the $\operatorname{Et}(\mathrm{OH})$ extract of $S$. carteri in BC cells, further study is conducting to advance analyze the molecular mechanism of this extract inhibiting cell survival, cell migration, as well as cell proliferation. We also want to further isolate the active compounds from this extract.

In conclusion, our data indicate a potential anti-cancer activity of ethanol extract of $S$. carteri in breast cancer cells. This research is also expected to become a consideration in escalating acquaintance of marine sponge from Indonesia.

\section{Funding Statement}

This OCEAN project is supported by Competence Research Grant from Universitas Padjadjaran for MHB (no.2476/UN6.C/LT/2018) and a research grant (3670/UN6.C/LT/2018) by the Ministry of Research, Technology, and Higher Education of the Republic of Indonesia.

\section{Statement conflict of Interest}

No potential conflict of interest was reported by the authors.

\section{Acknowledgements}

We thank to Fisheries Diving Club Bogor Agricultural University and Mr. Agus Erdina who supported for collecting samples in Pramuka Island; Mrs. Pratiwi, Apt. from Dr. Hasan Sadikin Hospital, Bandung, Indonesia who provided chemotherapy drugs; and Dina Sofiana, MD for contributing in this manuscript.

\section{References}

Aungsumart S, Vaeteewoottacharn K, Chamutpong S, Ponglikitmongkol M (2007). Chemo-radio resistance in cervical cancer induced by HPV16 E7. Sci Asia, 33, 5-11.

Bashari MH, Fan F, Vallet S, et al (2016). Mcl-1 confers protection of Her2-positive breast cancer cells to hypoxia: therapeutic implications. Breast Cancer Res, 18, 26.

Biegelmeyer R, Schröder R, Rambo DF, et al (2015). Cytotoxic effects on tumour cell lines of fatty acids from the marine sponge S copalina ruetzleri. J Pharm Pharmacol, 67, 746-53.

Candida N, Alfredo C, Patrizia R (2012). Anticancer drug discovery from the marine environment. Recent Pat Anticancer Drug Discov, 7, 218-32.

Chou TC (2010). Drug combination studies and their synergy quantification using the chou-talalay method. Cancer Res, 70, 440-6.

Dewi AS (2017). When East meets West: the chemistry of Indonesian sponges and Australian nudibranchs. The University of Queensland.

Eder C, Proksch P, Wray V, et al (1999). New alkaloids from the indopacific sponge Stylissa carteri. J Nat Prod, 62, 184-7.

Erpenbeck D, Aryasari R, Benning S, et al (2017). Diversity of two widespread Indo-Pacific demosponge species revisited. Mar Biodivers, 47, 1035-43.

Guzmán EA, Xu Q, Pitts TP, et al (2016). Leiodermatolide, a novel marine natural product, has potent cytotoxic and antimitotic activity against cancer cells, appears to affect microtubule dynamics, and exhibits antitumor activity. Int J Cancer, 139, 2116-26.

Hamed ANE, Schmitz R, Bergermann A, et al (2018). Bioactive pyrrole alkaloids isolated from the Red Sea: marine sponge Stylissa carteri. Zeitschrift für Naturforsch C, 73, 199-210.

Hammond WA, Swaika A, Mody K (2016). Pharmacologic resistance in colorectal cancer: a review. Ther Adv Med Oncol, 8, 57-84.

Hardani IN, Damara FA, Nugrahani AD, Bashari MH (2018). Ethanol extract of Stylissa carteri induces cell death in parental and paclitaxel-resistant cervical cancer cells. Int $J$ Integr Heal Sci, 6, 91-6.

Hsieh T-H, Tsai C-F, Hsu C-Y, et al (2012). Phthalates induce proliferation and invasiveness of estrogen receptor-negative breast cancer through the AhR/HDAC6/c-Myc signaling pathway. FASEB J, 26, 778-87.

O'Rourke A, Kremb S, Bader T, et al (2016). Alkaloids from the sponge Stylissa carteri present prospective scaffolds for the inhibition of human immunodeficiency Virus 1 (HIV-1). Mar Drugs, 14, 28.

Sima P, Vetvicka V (2011). Bioactive substances with anti-neoplastic efficacy from marine invertebrates: Bryozoa, Mollusca, Echinodermata and Urochordata. World J Clin Oncol, 2, 362-6.

Torre LA, Bray F, Siegel RL, et al (2015). Global cancer statistics, 2012. CA Cancer J Clin, 65, 87-108.

Vallet S, Bashari MH, Fan F-J, et al (2016). Pre-osteoblasts stimulate migration of breast cancer cells via the HGF/MET Pathway (C-H Tang, Ed.). PLoS One, 11, e0150507.

Vetvicka V, Vetvickova J (2016). Essential oils from Thyme (Thymus vulgaris): chemical composition and biological effects in mouse model. J Med Food, 19, 1180-7.

Wójtowicz AK, Szychowski KA, Wnuk A, Kajta M (2017). Dibutyl Phthalate (DBP)-induced apoptosis and neurotoxicity

Asian Pacific Journal of Cancer Prevention, Vol 20 
Muhammad Hasan Bashari et al

are mediated via the Aryl Hydrocarbon Receptor (AhR) but not by Estrogen Receptor Alpha (ER $\alpha)$, Estrogen Receptor Beta (ER $\beta$ ), or Peroxisome Proliferator-Activated Receptor Gamma (PPAR $\gamma$ ) in Mouse C. Neurotox Res, 31, 77-89.

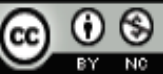

This work is licensed under a Creative Commons AttributionNon Commercial 4.0 International License. 